\title{
Agencies in Three South Eastern European Countries: Politics, Expertise and Law
}

\author{
Ivan Koprić, Polonca Kovač, Anamarija Musa
}

\begin{abstract}
Agencies are an organisational form with regulatory, expert or executive tasks that may ensure better usage of expertise compared to traditional administrative organisations. However, there are certain unintentional effects of the agency model, which are more obvious in transitional countries. Coordination and policy coherence gaps may raise the question of political accountability, provoke robust political interventions, and undermine the level of autonomy and expertise, especially where a firm legal framework does not limit the influence of politics. Another problem is the effective legal control over agencies. Traditional, bureaucratic legal procedures of internal control and courts' supervision in certain transition countries, like those researched in the paper (Slovenia, Croatia and Montenegro), are not fully suitable and effective for agencies, opening significant room for politicisation hidden behind expertise. The recent proliferation of agencies in those countries causes many new problems of public administration and enhances old ones. Interview-based research conducted in three countries in January 2012 has the purpose to establish the main problems and issues in the functioning of agencies, especially with regard to the legal aspect of agency and politics/policy relations. Basic findings confirm the hypothesis that the agency model in those countries has not been stabilised yet. Professionalism, autonomy and expertise of the agencies are in a precarious position. The legal framework for agencies should be fine-tuned and strengthened, to ensure proper steering within the agency model.
\end{abstract}

Key words: agency, agencification, public-administration reform, Slovenia, Croatia, Montenegro, politicisation, law, professionalism, Europeanisation 


\section{Introduction - the context of SEE transition countries}

Agencification is a broad trend, not only in Western Europe or in the anglophone world (see Verhoest et al. 2012). South Eastern European countries are influenced by the trend, too. ${ }^{1}$ Managerially inspired administrative reforms, a new concept of services of general economic interest - with independent regulatory bodies as an integral component - and the European Union's pressure towards the current candidate countries to implement the new concept during accession negotiations, technical assistance particularities and domestic muddling-through the Scylla and Charybdis of administrative development, are among the main drivers of agencification in SEE countries (see also Musa and Koprić 2011).

Semi-autonomous and autonomous administrative organisations have a rather long tradition in the region. There are various forms of organisations, emerging within the notion of "agencies", like executive agencies within ministries or autonomous public agencies with a legal personality. These two types correspond to the distinction between type- 1 and type- 2 agencies within the typology developed by Van Thiel (2012). Type-1 agencies are semi-autonomous organisations without legal independence, but with some managerial autonomy within state administration, while type- 2 agencies are those that are legally dependent and based on the statutes, with managerial autonomy. ${ }^{2}$

The problem of controlling agencies and leaving them a significant degree of autonomy for the performance of their tasks is a key issue of the agency model, although it is reflected differently with regard to the two types of agencies (Verhoest et al. 2011; Christensen and Lægreid 2006). The issue of autonomy is especially relevant for the type- 2 agencies. Their autonomy is usually secured in several aspects: organisational, legal, functional, procedural, financial, and with regard to personnel (Kovač and Virant 2011, 71-73). The independence of agencies is, nevertheless, relative and can be intensified or reduced, but it is not allowed to finally annul the impact of democratically elected authorities and users. On the contrary, the principles of the rule of law and the social state, and common (public) interest are affected (Pirnat 2004; Verhoest et al. 2011).

In addition, there is a long tradition of general administrative procedural law and of court control over public administration. Accordingly, all public bodies have to apply the principles and provisions of general administrative procedural law, with two-instance proceedings as a result (Koprić 2011b). This is not in line with the standards and requirements for independent regulatory bodies and can cause certain legal problems for other agencies. Furthermore, the standards from Article 6 of

1 The term South Eastern Europe is used here as a geographical notion. All three countries are usually referred to as CEE (Central and Eastern European) countries, meaning new democracies in transition after the fall of communism in Europe. Montenegro, and often Croatia, are also referred to as the Western Balkans.

2 Type-3 and type-4 organisations are outside the focus of the paper. 
the European Convention of Human Rights and Fundamental Freedoms (ECHR) ultimately require a two-tier system of administrative justice with administrative dispute of full jurisdiction, public hearing, the right to appeal to the higher court, and the protection of issuing administrative decisions within a reasonable time. When applied to agencies, this can substantially undermine their autonomy, too. Such a solution allows for too deep intervention of the administrative judiciary into agency matters (judicialisation).

This paper presents the research on agencification in Slovenia, Croatia and Montenegro, indicating the main problems connected to the agency model in the three countries, as they are perceived by the interviewees, in the areas of legal framework and control, expertise and effectiveness of agencies, the role of politics in managing and controlling agencies, and the role of agencies in policy-making. Building on previous legal analysis of agency frameworks in the three countries, the research was based on 32 semi-structured interviews with officials in the three countries that were conducted in January 2012. The goal was to obtain information on the perception of the main problems of agencies and their ranking, as well as on the issues that need to be further researched. ${ }^{3}$

After presenting some similarities and differences between the three countries in chapter 2, agencification patterns and agency design issues are presented, following a brief introduction to the administrative reform process in the respective country (chapters $3-5$ ). In chapter 6 , the findings are discussed and some directions for further research are conceptualised.

\section{The triplets of the European South East? Some similarities and differences of the three countries}

All three states share certain common characteristics, but also exhibit significant differences (Appendix; see also Koprić 2012). It seems that Slovenia and Croatia share more commonalities, while Montenegro is a slightly different case. However, having in mind the significant common Yugoslav experience and other commonalities, one can predict certain similarities in the agencification process, too, although with a certain time shift, mainly because of the different pace of Europeanisation.

3 The interviewees are 17 agency managers, 7 administrative court judges, and 8 politicians and high-ranking officials from the ministries, with different educational backgrounds (law, economics, science, medicine) and professional experience (politics, judiciary, state and public administration; some have served in various agencies; some were political party officials; etc.). The interviews encompassed a set of open-ended questions related to legal issues (legal framework, ex-ante and ex-post control of legality), politics (the issues of politicisation, political control, policy-making), and expertise, autonomy and effectiveness. The researchers had the freedom to adapt the questions to the individual interviewee, his/her background and professional experience. At the end, the interviewees were asked to rank the problems of the agency as they perceive them with regard to their importance. 
The first commonality is the development within a common state during a relatively long period. All three countries were part of the first Yugoslavia (1918-1941) and the second, socialist federative Yugoslavia (1945-1990). Before that, Croatia and Slovenia were part of the Habsburg Monarchy and the Austro-Hungarian Monarchy for approximately 400 years (Slovenia from the mid $15^{\text {th }}$, Croatia from the early $16^{\text {th }}$ century); Montenegro was part of the Ottoman Empire (end of the $15^{\text {th }}$ - mid $19^{\text {th }}$ century). As shown in Koprić (2012), the special mix of historical legacy and legalistic administrative country might be conducive to a type of muddled governance in the whole SEE region, where the ongoing administrative reforms have a task, to a different degree, to fight politicisation, corruption, as well as the inertia of formalism and rigid administrative structures.

Secondly, all three states went through the process of independent state building, democratic transition, and post-war stabilisation in the last two decades. Slovenia and Croatia declared their independence in 1991, while Montenegro continued to share statehood with Serbia until 2006. The efforts to build completely new political, administrative, legal and economic systems were connected to the processes of state building (army, customs service, diplomatic service, policy-making). Those efforts put great pressure on the institutional, human and financial capacities. Moreover, the aggression of the Yugoslav Army against Croatia, joined with the rebellion of the Serbian minority in Croatia 1991-1995, and Montenegro's participation in the war during the 1990s, hindered democratisation and caused many other post-war problems. These developments have influenced the different speed of the transition process, and the different level of democracy and the rule of law in the three countries. Although one can predict variations in social, political and administrative cultures, it seems that all three countries are characterised by the authoritarian culture, deep politicisation, and moderate political legitimacy (see also Koprić 2012).

Thirdly, all three states have established EU accession as the main foreign policy goal, but its progress developed at different speeds - Slovenia became an EU member in 2004, Croatia is expecting membership in 2013, while Montenegro started negotiations in 2012. The EU accession policy has led to significant efforts of political and administrative elites in order to meet EU requirements. The most visible result is a shallow Europeanisation on the level of convergence of discourse and decisions (see Pollitt 2004). Moreover, all three countries have tried to harmonise with the acquis communautaire in different policy sectors and to reform their public administrations according to the European administrative standards supported by the OECD-EU joint venture Sigma (Olsen 2003; Koprić et al. 2012). They exhibit elements of convergence under the EU reform pressures, like other transition countries (cf. Goetz 2005; Schimmelfennig and Sedelemeier 2005).

Furthermore, the three countries belong to the group of small(er) states. Slovenia and Montenegro fall into the category of small states, which is usually set at two million, but Croatia can also be considered a smaller state (see data in the 
Appendix). The factor of small country size might be regarded as conducive to the constraints posed by the economy of scale to both the general socio-economic development (see Šević 2001), to public administration and institutional development (Sarapuu 2010; Brown 2010), especially with regard to higher politicisation, civil society-state relations (dense social networks can capture state), lack of human resources and expertise, and weak administrative capacities. Some studies underline the importance of individuals and personal relationships, multi-functionalism of jobs and employment of rare specialists in small states and suggest that the "higher degree of 'personalism' in small states causes more 'flexible' adoption of administrative rules as opposed to the values of rationality and universality in bureaucratic systems" (Randma-Liiv 2002). Finally, the smallness of the country might have a negative effect on the speed and quality of the institutional and especially on administrative capacity development, which is a key element of the development in the transition period.

Due to the commonalities, one can expect similarities in the agencification processes, but there are important differences between the countries that can lead agencification into different directions. Firstly, the three states have different territorial organisations. Croatia has two tiers of local governments; Slovenia and Montenegro have only the municipal level (see Appendix). Local governance systems are more fragmented in Slovenia and Croatia (average municipality with 9,712 and 7,716 inhabitants respectively), while local units in Montenegro are rather large (29,775 inhabitants on average). The ethnic issue is the most prominent in Montenegro, with only 45 per cent of Montenegrins and 29 per cent of Serbs, while in Croatia (90 per cent of Croats) and in Slovenia (83 per cent of Slovenes), the societies are more homogenous. All three countries are parliamentary democracies, with Slovenia and Croatia directly electing the president.

With regard to economic development, the three states differ significantly. The GDP PPP rates indicate that Slovenia's economic development is among the highest within the group of all CEE countries, while Croatia's GDP is comparable to the average of CEE countries. In comparison to that, Montenegro's GDP is almost three times lower than Slovenia's and comparable to the lowest GDP in CEE member states. Still, all three states were hit hard by the economic and financial crisis, especially Slovenia and Croatia, which, respectively, suffered a -8.0 and -6.0 growth in 2009 , but the Croatian GDP growth rate remained negative in 2010. Croatia also suffers from high unemployment (9.1 in 2009 with a tendency of growth). The effects of the economic crisis were felt in the reorganisation of state administration in 2010 (Croatia), 2011 (Montenegro), and 2012 (Croatia, Slovenia).

Finally, there is a significant difference between the three countries in relation to the government effectiveness, the quality of regulation and the rule of law, as well as to e-government and the degree of supportiveness of the political, administrative and economic environments to economic development. In comparison to 
Montenegro, Slovenia and Croatia rank higher with regard to the government effectiveness, regulatory quality and e-government (Appendix). Croatia and Montenegro are more similar with respect to the rule of law and corruption perception. In contrast, Croatia is worst positioned when it comes to the index of doing business. These differences can be interpreted in terms of the different starting points, the general political and economic context, the duration of the reforms, and other socio-political characteristics.

\section{Agencies in Slovenia}

\subsection{General overview of administrative reform and agencification}

Slovenia performed its administrative reforms mainly within the process of Europeanisation (Kovač 2011). Public administration is rather efficient and professionally competent, with politicisation and lack of professionalism persisting from the earlier transition period (cf. Pirnat 2004; Kovač and Virant 2011). The legal framework complies with the EU's standards. Administrative reforms were strategically planned and implemented. Slovenia underwent the paths of revolution (1990-1994), transition (1995-1997), EU accession and integration (1996-2004), further modernisation (2003-2008), and adjustments induced by the economic crisis (2008-2013). The main reform processes are modernisation and Europeanisation (cf. Koprić 2012). The harmonisation of national legislation with the EU requirements has been coordinated by the Governmental Office for EU Affairs since 1996. Both internal and external driving forces (especially Europeanisation and the New Public Management) have led Slovenia to introduce certain reforms tackling organisation and structure, civil service, public finances, administrative procedures, e-government, etc. Administrative reforms have been very successful in an operational and technical sense (e.g. harmonisation with EU law, TQM, elimination of administrative barriers), and less so concerning the local government system and the decentralisation of public services (Kovač 2011). The reforms have been designed in a neo-liberalistic fashion and carried out rather legalistically, but are pursuing some good governance principles (e.g. customer orientation).

The idea of independent public agencies was closely linked to the privatisation of (economic) public services (Pirnat 2004). The EU has had a significant impact on the agencification in fields like market security, insurance supervision, energy supply and telecommunications, where the agencies have had a high level of legal and managerial autonomy (type-2 agencies). There are also fields in need of such autonomy, such as food safety. The key goals of establishing (new) public agencies were to divide strategic policy-making from implementation (steering from rowing, cf. Pollitt and Talbot 2004) and to strive for political neutrality of professionally driven implementation with relative independence from the daily politics and short-term particular interest of the parties in power (Kovač 2006, 261-267). Type- 
2 public agencies were usually transformed from the already existing departments within the ministries (bodies within ministries, organi $v$ sestavi ministrstev, cf. Next steps agencies, Pollitt and Talbot 2004; type-1 agencies cf. Van Thiel 2012, 20-24). This process was not systematically conducted, since there is still a large number of executive agencies within the ministries (about 40 in June 2012), although some of them could be in need for more autonomy.

The increase of the public agencies can be observed: from one established in 1994 and five in 2000 to 16 established in 2010, and 18 in 2012. The majority of them function in the field of finances and economy. In 2011, the Government designed a solid reform programme concerning public agencies (Vlada 2011; interviews 2012). It is oriented towards rationalisation of the public sector, including a 10 -per-cent reduction of management costs, improvement of internal management systems, outsourcing, etc. The budgetary resources are to be allocated in accordance with the programmes and public services (as a key element of good governance, cf. Verhoest et al. 2011), unlike the present allocation to the organisations. Having in mind the 2011 macroeconomic indicators, the new 2012 Government decided to introduce radical short-term measures, such as merging or abolishing several agencies by the end of $2012,{ }^{4}$ despite the fact that some of them were newly established in 2010 or 2011.

\subsection{Legal framework and legal control of the agencies}

In 2002, Slovenia adopted a package of reform legislation, including the Law on Public Agencies (LPA) and the Law on the State Administration, which created a legal basis for systematic agencification. The main purposes were deconcentration, rationalisation and professionalisation of public administration. Several models of autonomous entities have developed with different levels of autonomy even within the same organisational type such as public agencies (Bohinc 2005, cf. Pollitt and Talbot 2004). Pursuant to the LPA, a public agency is an independent legal entity, founded by the state or a municipality with the purpose of more efficient execution of administrative tasks or in cases when constant political supervision over task implementation is not necessary or appropriate. The LPA regulates the establishment of an agency, its bodies (council and director), competencies, tasks and activities, supervision, relations between the agency and its line ministry (or ministries), relations with users, transparency standards, financing, etc. The council consists of the members appointed by the founder, and by the representatives of the users (whose number ranges from one third to one half). It takes care of the public interest, issues by-laws, an annual programme, plans and reports. The director has a five-year mandate; he/she represents the agency, decides in individual cases, and is responsible to the ministry on the basis of the performance contract. Because of that, public agen-

4 Mergers are inspired by the neo-liberal ideology: one new agency will replace five of them in the financial sector, some agencies will be reshaped as parts of the respective ministries (for example, Traffic Safety Agency), etc. 
cies in Slovenia can be classified among legally independent bodies (type 2; cf. Van Thiel 2012, 20). Their emergence compared to global trends puts Slovenia within the ratio of 2:1 between executive and independent public agencies, which is closer to the group of CEE countries (with about a 10:3 ratio), than to SEE countries (with about a 3:10 ratio; Van Thiel 2012, 23).

The employees in public agencies are treated as civil servants, albeit only several chapters of the Law on the Civil Service (2003) are applicable to public agencies. This leads to a slightly different legal status of agency personnel, in comparison to the civil servants in state administration. Pursuant to the sectoral laws, agency employees are mostly included in the common governmental personnel plan, which is a Government's tool for limiting the employment in and resources of the agencies. The majority of interviewees in Slovenia, however, hope for a less rigorous legal framework regarding the management of organisation and human-resource management (i.e. wider managerial autonomy).

Public agencies act as public authority holders ex imperio, issuing secondary legislation and deciding in individual administrative cases on the basis and within the scope of sectoral laws (with acts de iure gestionis; details in Kovač 2006). Lex specialis usually introduces special procedural rules, different from those in the Law on General Administrative Procedure (LGAP) and the Law on the Administrative Dispute (LAD), to speed up decision-making with limited participation of the parties (i.e. users), exclusion of oral hearing, shorter terms, non-suspension effect or even exclusion of the right to appeal, limited mandate of supervisory bodies, etc. (Pirnat 2000). Some of these provisions have been assessed by the Constitutional Court as the breach of the Constitutional provision on equal protection of the rights (Article 22), but more often, the Court has found special clauses to be reasonable according to the field particularities. The Administrative Court carries out judicial review of the agencies' decisions in individual cases, which is appropriate in the opinion of all interviewees. However, as stated by an experienced Slovenian administrative judge, there is "an urgency to develop expertise and professional competence of the decision-makers in administrative procedures and to institutionalise alternative dispute resolutions in administrative matters" (ADR is not provided for in public law). The most frequent pitfall within judicial review is the insufficient statement of grounds for decisions and restrictions/deprivation of the right of a party to be heard and informed about the basic circumstances and facts relevant to the administrative decision prior to its issuing.

\subsection{Expertise, effectiveness and politicisation of the agencies}

There are several driving forces of the agencification process in Slovenia - harmonisation with the EU and strife for efficiency and effectiveness being dominant. The number of public agencies at the state level therefore increased, especially before full EU membership (2000-2004) and in the period of global economic crisis 
(2009-2011). The biggest problems, felt especially by the managers of some agencies involved in the research, are the lack of vision, guidelines or public policy concerning the question which public competences should be delegated to independent agencies. "The effect of Europeanisation is visible only in legislation, while good governance and agency management seems to be unaffected by the European trends", is the common observation of several interviewed representatives of the line ministries and of an administrative judge. Such a situation is partially a consequence of the transitional heritage, i.e. of the lack of professional public management and well-designed public policies. All interviewees find expertise and professionalism (along with political independence) as the key bases of true agency autonomy. They also state the need for performance contracts, increased transparency and better coordination between agencies and ministries. The current form of reporting is not the appropriate performance measurement tool - the agencies report about their activities, acts, events, finances etc. but rarely about the achieved outcomes. The ministry and the agency should be both responsible for the agency's results - if there is damage done, the liability should lie with the ministry if it is in its field of competence (cf. Polidano 1999).

The current economic crisis strongly influences the resources at agencies' disposal. An observation of several interviewees is that there is the possibility of the emergence of capture problem. Slovenia is a small state with a limited number of field experts, many of them with previous experience and expertise in the regulated market. Because of that, some former directors of the companies operating in the respective fields become members of the agencies' councils. Thus, they frequently act as the representatives of particular interests rather than of the public interest. Interviewees reported that there is a need to exclude agency employees from the civil service and from the unified public remuneration system. The number of employees in agencies varies significantly (from 3 to 250 ; the total being about 800 in 2012). In general, the system of financing ought to be improved according to the unanimous conviction of heads of several agencies and politicians in ministries (interviews 2012). Some agencies (Security Market, Traffic Safety, Public Records etc.) are financed from 40 to 100 per cent with non-budgetary revenues, but the majority is budget-dependent despite the fact that they are formally allowed to have their own revenues.

Empirical research proves that legal aspects are the important but insufficient condition to achieve the desired independence and political neutrality in praxis. As stated in one interview: "The guarantees of independence of agencies in the LPA are rather formal. What is more important is that there should be a clear line in the statute of the particular agency as to which aspect of the agency's independence should be guaranteed and in which cases policy considerations governed by political leaders affecting the work of agency are quite legitimate." Two major problems arise: non-systematic differences of the autonomy level in various types of organisation (de facto lower independence in the entities that de iure should be autonomous; cf. 
Pirnat 2004; Virant 2004); and discrepancy between autonomy and responsibility. There is a common conviction that the appointment and change of agencies' heads must not be in the hands of the Government. According to the ministries and agency heads included in the research, the impact of politics in the appointment procedure for agency heads is insignificant, probably due to obligatory public tender. However, according to the experience of the judge interviewed, the most frequent administrative disputes concern the appointments of agency directors, because of the poor quality of selection procedure.

As the most prominent issues, the interviewees report that the agencies' status has not been regulated, and that the agencies are not perceived as the most relevant or efficient tool for policy implementation. It has been argued that there should be a clear distinction between regulatory agencies and other agencies connected to the ministries. The level of autonomy is rising over time, with a different pace of agencification in individual fields. One of the obstacles is the lack of agency-model tradition. The key improvements of a new agency regulation in Slovenia should cover the financial, managerial and other prerequisites for their autonomy, and modern tools for effective control over agencies, like performance measurement and policy evaluation.

\section{Agencies in Croatia}

\subsection{General overview of administrative reform and agencification}

The development of the Croatian governance system can be divided into two phases. The 1990-2000 phase was marked by state building, devastating war (1991-1995), expensive post-war reconstruction, slow democratisation, non-transparent privatisation, and the introduction of the free market economy. Unfavourable economic and social circumstances and the strong semi-presidential political regime with authoritarian features had retarded political development, reinforcing the negative side effects of transition, such as corruption, politicisation and social inequalities. The second phase began in 2000 when the processes of democratisation, decentralisation and EU accession were initiated by the left-wing coalition in power. Nevertheless, the political and administrative tradition based on the strong state is still heavily influencing political and administrative development. Some of the indicators are haphazard administrative reform, hesitating decentralisation, weak institutions and underdeveloped civil society. In such circumstances, public administration went through the phases of establishment (1990-1993), consolidation (1993-2001) and Europeanisation (after 2001), with prospects for modernisation after 2008 (Koprić 2011a). The three most prominent elements of the state administration reform refer to the civil-service system, administrative procedures and administrative disputes. At the same time, the organisational changes were introduced sporadically while some key elements of neo-managerial approach, such as perfor- 
mance management, pay-for-performance, and quality management, were absent from the reform agenda.

The agencification process reveals features of high intensity, incoherence, and the absence of a common legal framework for the establishment and functioning of agencies (see Musa and Koprić 2011). There are approximately 70 agencies with a legal personality, with regulatory, executive, expert, development or standardisation tasks (type-2 agencies); and approximately 15 semi-autonomous organisations within the central state administration (type- 1 agencies). The majority of type- 2 agencies were created based on the 1993 Law on Institutions, while independent regulators and some executive-type agencies were created outside the systemic legal framework. Type-1 agencies are within the general state-administration legal framework, which grants them lower autonomy and more intensive political control in comparison to type-2 agencies.

The agency is not a new organisational form in Croatia, since decentralised forms of public administrative bodies existed in the socialist period as a consequence of the self-management ideology. The agencification process had the strongest impetus during the period 2001-2009, when the number of agencies grew from 22 to 75 . The main drivers of agencification were the EU accession negotiations and the absence of systemic legal regulation that allows wider autonomy to the agencies. In contrast, the financial and economic crisis caused a shift in the agencification process in 2010. Only two new agencies were founded that year, and 15 agencies were abolished, leading to a decrease of 20 per cent in the number of agencies (to 63 ), with only three agencies established in 2012. In order to rationalise the agency landscape and to minimise expenses, the new Government started the review of agency governance in 2012 with consequences that are still unknown.

Agencies have to decide in individual cases in line with general administrative procedural regulation. First-instance decisions of the majority of executive agencies are subjected to the second-instance legality control by their line ministries. The decisions of line ministries are controlled by the administrative courts. The reformed administrative justice system is based on two-instance administrative dispute, full jurisdiction and public hearings. The managerial autonomy of the agencies is wide, since the only restriction is financial; but regulatory agencies have significantly wider autonomy. The majority of agencies use the state budget and are subjected to the control of the State Audit Office, but some of them, mostly regulators, are not audited. Annual reports are submitted to various institutions - to Parliament, Government or the line ministry and, in some cases, to the EU institutions. The civil service framework does not apply to the employees in type- 2 agencies, who are either subjected to the Labour Act or, in the case of some executive and expert agencies, only to the Law on Salaries of Public Servants. However, in 2012, the Ministry of Public Administration started to prepare a harmonisation of rules for all public servants, type- 2 agencies included. Finally, agencies differ significantly with 
regard to democratic control and the participation of users or stakeholders in the functioning and organisation of public agencies. Expert agencies usually engage the representatives of users, professional groups and academia.

\subsection{Legal framework and legal control of the agencies}

The absence of a general legal framework for agencies which would differentiate between various types of agencies (regulatory, executive, or state agencies and government agencies) and determine the strict rules for appointment and dismissal of the board members, their functions, relationship with the line ministry, organisation, personnel requirements, funding, supervision (financial, administrative, performance management) and evaluation (by introducing a sunset clause), etc. is labelled problematic by all interviewees (agency heads, politicians, judges). The different legal basis for the establishment of agencies and frequent changes of legal acts establishing individual agencies have a negative influence on legal certainty, add additional costs, and allow the agencification process to progress without control. The interviewees accentuate that a better legal framework would lower the discretion of both politicians and agency management with regard to the establishment and organisation, but would also protect the agency from frequent changes and political and other pressures. Thus, a new organisational type, which has to be appropriately controlled, would be introduced. As one official from the Ministry of Administration argues, the creation of the "agency jungle that cannot be controlled" has happened because "nobody has really thought of what the nature of the agency is, only of the fact that it is a good instrument for escaping general rules."

The control of legality of the agency's decisions and other aspects of its functioning are subjected to the control of the judiciary, according to the Law on Administrative Disputes. As of 2012, agencies' decisions are subjected to a two-instance judicial review (an exception is the Croatian Postal and Electronic Communications Agency, whose decisions are reviewed only by the second-instance Higher Administrative Court), which makes the judicial review process considerably long. Judges are generally satisfied with the agencies' decisions and accentuate that they conform to the legality standards. They applaud the implementation of substantive (sectoral) laws, but find the application of general administrative procedural law slightly worse - to a bearable extent. Still, both judges and agency heads believe that the agency staff would profit from additional education and training in general administrative procedure and administrative dispute. The judges find agencies' decisions to be inspired by the decisions of EU institutions, which are rather detailed and comprehensive. Further, agency managers are satisfied with the work of the former Administrative Court. They confirm the educational value of the Court's decisions, accepting the criticism with regard to agencies' decisions, and recognising its reasoned opinions tend to direct agencies' application of administrative procedure and general legal principles in individual cases. Still, they are critical with regard to the Law on General Administrative Procedure, which applies to the decision-mak- 
ing of the agencies, because they find some of its provisions unsuitable for agencies (oral hearing, right to be heard, supervision of regulated sector, etc.).

Both agency heads and judges assess that judges have sufficient expertise, and state that at least some degree of specialisation for judges is necessary. However, they do not find a narrow specialisation to be an appropriate solution, because, as one agency head has underlined, "the judges could try to develop their own policy in the sector", or the "specialised" judge would be more prone to external pressures. The present situation allows judges to decide in various matters and to discuss all cases on the court general sessions. This makes the court more insulated from pressures and offers more transparency.

\subsection{Expertise, effectiveness and politicisation of the agencies}

Agency managers are satisfied with the quality of their staff and emphasise continuous education and training in both specialised fields and in general issues, such as administrative procedure. All of them have a certain level of freedom in determining the salaries and, in some cases, additional payments related to the performance, which together with the possibility of professional development and a more flexible and competitive work environment, makes the employment in an agency more attractive in comparison to the civil service. Some agencies use more complex performance appraisals, while some only generally assess their employees, which might be attributed to the different size of the researched agencies (ranging from 6 to 140 employees). The agency managers have not encountered problems related to employees leaving their agency - the vacancies are quickly filled with the new staff. Because all six agencies perform tasks that are relatively new (regulation of privatised sectors, quality assurance), they need some staff members with specific profiles that are not easy to find on the labour market. The necessity of additional education and training is accentuated by all agencies. The fact that some of the agencies sometimes fill their vacancies without public announcement is not seen as problematic with regard to the constitutional principle of equal access to the public services (Article $44)$, but is considered a component of the managerial freedom.

The perception of the ministries' capacities and willingness to cooperate with the agencies is different - some agency managers claim that their cooperation with the line ministry is quite good, while others report that the ministries are not able to cope with the complexity and fast developments. "Thinking outside of the box is not something a ministry would bother to do", implies an image of bureaucratic thinking. Some agency managers also underline the problem of horizontal institutions, such as the Government's Legislation Office and the Ministry of Administration, which do not recognise the agencies and their regulations as specific, different from the traditional administrative organisation and traditional way of rule-making. Some of the agencies develop annual goals and plans, connect specific activities to sectors and monitor their implementation. Still, the more precise performance 
measurement is not used, and has certainly not been defined by the line ministries. The agencies report to the ministries or to the Government and, some of them, also to the Parliament, but have not encountered problems with the approval of their reports. Agency managers believe that the lack of discussion about the reports, especially in the Parliament, has a negative impact on policy-making and problemsolving, because sometimes the Parliament is the only body that can determine the policy direction and set the priorities. This has a negative effect on the public-service markets, which are still in a nascent state (energy supply, for example), because the problems remain unsolved. Agency managers stress their good work, expertise and integrity, the legality of their decisions, their good international cooperation and their equal stand in the European and other networks, their leading role among the agencies in the region, as well as the accreditation from international bodies.

The agencies that collect their own revenues claim that they have wide financial autonomy, while others believe that their financial autonomy is seriously restricted by the Ministry of Finance. Moreover, the agencies are constantly adding new tasks to their portfolio, which is not followed by a proportional increase of their budgets. Some of the agencies claim that the comparative experience offers instruments for additional funding of the agencies, but they believe that in some cases this practice might give wrong signals to the agency (for example, if the fees were part of the agency budget, it might lead the agency to put more emphasis on sanctioning).

Agency managers acknowledge the existence of direct and indirect pressures from the regulated sector, mostly through the media trying to create a policy or direct the decision-making (e.g. the regulated subject is an important advertiser in the media). In order to prevent negative implications of the interwoven relations between the agency, regulated market and the state institutions in the same sector (due to the mobility of specialised staff and the small-size effect), they mostly put serious effort into establishing a transparent and formalised partnership and cooperation within the sector, by developing joint projects, education, designing the methodologies and guidelines, etc. The agency heads argue that the agency's value is measured by "the worth of its service" and "the integrity and expertise of its leadership".

From politicians' point of view, the autonomy of agencies goes well beyond their control, especially of those collecting 100 per cent of their revenues from the fees they charge. Some officials claim that there is no legal basis for employees being exempted from the public-service framework. They believe that the issue of salaries has to be solved systematically for the public sector in general. The parliamentary debates involving agencies turn out to be a way of political conflict between the governing and the opposition parties and not the means of solving problems. The hottest debates are those that might attract newspapers, involving some scandal. The agencies' reports are not carefully examined, but, as politicians say, they are only descriptive, not analytical reports that would help politicians to control the agen- 
cies. Moreover, there are neither clear criteria for monitoring the work of agencies nor performance standards. Administrative supervision over the agencies is almost non-existent. In fact, politicians believe that the main control instrument should be a speedy administrative court procedure. Another way to increase transparency and stop feeding the negative public picture the agencies have would be the creation of an Internet website with comprehensive data about the agencies.

Agency managers and politicians have different views on the issue of politicisation. Agency managers believe that the legal framework for all agencies should stipulate that the board members are appointed based on public announcement and that the composition of the board should ensure the diversity of specialisation and their independence. Some politicians believe that the agency boards should be politically appointed to ensure policy implementation and coordination, expressing the new Government concept of greater politicisation of the top levels of administrative organisations in order to enhance accountability and coordination mechanisms.

\section{Agencies in Montenegro}

\subsection{General overview of administrative reform and agencification}

The administrative reform started in 2003, when the Administrative Reform Strategy for the 2002-2009 Period and several relatively modern systemic laws were adopted (Marković 2007). The reform has been under the significant influence of the foreign technical-assistance projects. Various donors have tried to impose their administrative doctrines and ideas, which caused a patchwork-like system of public administration and administrative law. The reform is mainly oriented towards state administration and legal regulation of public administration (administrative procedures and justice). Local governance and public services attract far less reform attention (Lilić 2010). Two main drivers of agencification are domestic legal regulation based on the NPM notion about executive agencies (see, for example, Marković $2007,53,105-118$, etc.) and the EU influence, especially with regard to services of general economic interest. While the former provided the impetus to the development of numerous executive agencies, the latter was decisive for independent regulatory bodies and expert agencies.

According to the Law on State Administration System of 2003, ministries are bodies competent for policy formulation, law-drafting and administrative supervision, while other administrative bodies are competent for policy and law implementation. Because of this regulation, the state administration in Montenegro was rather complex and fragmented. In 2004, it consisted of 38 bodies: 15 ministries and 23 other bodies (10 administrations, 2 secretariats, 7 institutes and 4 directorates; Marković 2007, 179). A decade later, at the end of 2011, the number of state-admin- 
istrative bodies increased from 38 to 53 (40 per cent increase; 16 ministries and 37 other administrative bodies); about 20 new public agencies were established outside the state administrative system. Less than a decade elapsed after the 2003 Law, when the reorganisation of the Montenegrin state administration was implemented at the beginning of 2012, based on the Public Administration Reform Strategy for 2011-2016, titled AURUM paper, adopted by the Government in March 2010. Amendments to the Law on State Administration System of 2011 allow mergers of public agencies (type 2) and their incorporation as the semi-autonomous bodies within the ministries (organ $u$ sastavu ministarstva; type 1). Both types of agencies ( 1 and 2) are part of a general administrative and civil-service framework.

The 2012 reform aimed to address the main deficiencies of public administration: high fragmentation, absence of clear responsibility lines, and lack of coherence and policy coordination between the administrative bodies. Moreover, the delimitation between ministries and agencies was not clear, despite a clear legal regulation, with consequences to the blurred lines of accountability. This situation had a negative impact on the efficiency and effectiveness, but also on the perception of state administration by the public. The main drivers of the 2012 mini-reform were the economic and financial crisis and the fight against corruption. The Government prepared the document, issued in November 2011, with proposals for the dissolution of several agencies and administrative bodies, their mergers with the ministries, stronger control of the ministries over functioning, public procurements and financing of previously semi-autonomous bodies and agencies, etc. The preparation of a systemic piece of legislation on agencies is also mentioned as one of the reform measures, but it has not been prepared so far.

There are six agencies within the state administration (type-1 agencies), as well as numerous independent regulators and expert agencies outside state administration (type-2 agencies). Type- 2 agencies were established during the last decade, beginning with the Telecommunications Agency in 2000. Most of them were established during the second part of the 2000s, after Montenegro declared independence. There are many bodies at the central level that might be classified as type-2 agencies, although they have other names, such as administration (uprava), institute (zavod), board (direkcija), etc.

The reorganisation of the state administration started in January 2012 with the stronger emphasis on integration and coordination of state administration that led to a significant decrease in the number of executive agencies - from 37 to 14 . At the same time, about 20 independent regulatory bodies and expert agencies are not directly affected by this reorganisation, although the pressure on them can be easily observed. 


\subsection{Legal framework and legal control of the agencies}

Several interviewees consider that the systemic legal regulation of the agencies and more precise regulation of the state administration would add to institutional stability and better performance of both types of bodies (agencies and traditional administrations). The preparation of such a law was planned by the Public Administration Reform Strategy for 2003-2009, and again by the Aurum Paper (2011-2016). The existing legal position of independent regulatory agencies is still not fully in line with the European standards. For example, in individual cases resolved by the Agency for Electronic Communications and Postal Services there is a possibility for appeal to be lodged to the competent ministry, which means that the Agency's decision is not final or independent from the political influence of the Government and state administration. Furthermore, the competent ministry and other government bodies are playing waiting games, making adoption of the secondary legislation necessary for the realisation of regulators' autonomy difficult or even impossible for a long period of time.

In some agencies, administrative procedures about the rights and obligations are conducted by the staff members that are not legally educated, causing many disputes before the Administrative Court. The main procedural law, the Montenegrin LGAP, is - according to the interviewees - not fully applicable and suitable for administrative procedures in agencies. Certain agencies have managed to influence the content of special procedural laws, so they could be easily applicable, but some of those laws are of low quality. Even the Law on Administrative Dispute is reported not to be adequate for the cases in which agencies are a party in the dispute, because these cases are occasionally extremely complicated. Numerous new kinds of court cases have appeared since the establishment of the first independent regulatory bodies. The Administrative Court's capacity is stretched thin by such a development, because the number of judges is rather small and they cannot specialise in so many different agency matters. Still, agencies are recognised by consumers as a well-functioning mechanism for the protection of their rights with regard to service providers. Because of that, the number of complaints to the agencies against various service providers is ever increasing.

Most interviewees argue that the courts are not well prepared for the new issues connected with services of general economic interest, especially with regard to the European acquis that is or has to be implemented. Regulations are very detailed and specific, and should be transposed by domestic laws and subsequent secondary legislation by domestic independent regulatory bodies. However, according to the interviewees, the courts' approach is old-fashioned and very formalistic, and they see a possible problem with the application of European law by the courts. Judges are not educated and trained in the new issues. They are not inclined to accept the new position of agencies, different from the position of traditional administrative bodies. New issues are not included in the study programmes at the faculties of 
law. There are no training courses in agency matters for judges and personnel of the Administrative Court. This perpetuates the difficulties with accepting new legal and administrative solutions. However, the courts were able to prevent unlawful decisions of some agencies in certain cases. This indicates an overall readiness of the courts to defend the rule of law, as well as the need of intensive training of judges and courts' professional staff in issues of the agency model.

\subsection{Expertise, effectiveness and politicisation of the agencies}

The interviewees believe that there should be a proper mechanism to evaluate the functioning and existence of the agency. They consider the sunset clause for agencies as the proper generator of agencies' accountability and rationalisation of the system, accompanied by the introduction of performance standards. If the sunset clause existed, monitoring and periodical assessments of agencies' performance and outcomes would be less political, less emotional and less stressful. It would add to the development of a thorough performance-management system in the whole public administration. Still, even now, annual reports made by the agencies are a step ahead in the performance-management system, because traditional administrative bodies are still not subject to regular reporting. Annual reports of regulatory and expert agencies attract enormous political and public interest, and parliamentary debates on them are very intensive. As one of the interviewees said, "Agencies are under stricter control of the Government and the Parliament, because only agencies are subject to regular annual reporting." Agencies are obliged to submit an annual financial report and an annual report on their functioning and results. However, as indicated by the interviewees, there is a lot of space for the development of proper performance indicators to enhance the capacity of ministries that should be an equal partner of the agencies.

The problem of Montenegrin public administration relates to a low capacity of the social, economic, administrative, and educational bases of society, which are expected to serve as the source for the complex organisational development. In such circumstances, the design of the agency model should be extremely attentive and precise. Otherwise, the damage can outweigh possible positive effects of the agency model. Montenegro follows Slovenia and Croatia in its general endeavour to join the EU and in building its own agency model, repeating certain mistakes and adding its own. However, many of them are caused by specific circumstances (smallness of the country, scarce resources, short period of independence, attempts to speed up the process of Europeanisation, etc.).

Illegitimate political influence tends to be legally channelled into the system. There is constant pressure within the Government and the Parliament aimed at introducing effective political accountability of regulatory and expert agencies' management. Parliamentary discussions about agencies' annual reports have called for a possibility to remove the agencies' management and boards and to appoint new 
ones. Furthermore, there is an unacceptable practice of the ministries that tend to adopt parallel regulations of the issues that should be regulated by the independent regulatory bodies, but in a different manner. There is a real risk that such regulations are not in line with the acquis communautaire. Sectoral regulations in many regulatory and administrative fields - be they drafted by the agencies or by the ministries - are more or less harmonised with European standards. Agencies have had a significant role in the harmonisation process, because they are devoted to their fields and dedicated to acquiring European standards (data protection, environment protection, telecommunications, etc.). Moreover, the interviewees report that the agencies are very frequently asked to prepare draft legislation for and instead of their line ministries, because the ministries do not have proper expertise and capacity for such efforts. This underlines the frequent critique that the main administrative capacity problem is not in the agencies, but in the core state administration, which is insufficiently professional, heavily politicised and insufficiently transparent. In other words, the agencies are seen, mostly by their managers and by certain other interviewees, as the islands of expertise.

The size of the country was reported as being very significant for various issues related to agencification and administrative reform, narrowing the distance between the agencies and political bodies, as well as between the agencies and the regulated sectors and business firms. It is also related to the problem of specialisation and expertise. The resulting politicisation of agencies prevents the institutionalisation of meritocracy (see also Parrado and Salvador 2011). Their management has to be flexible with regard to various unlawful influences (with regard to personnel, for example, employing relatives of important persons) in order to win political and public support, to be able to protect minimal independence in their subject matter, and to stick to the European standards. All other bodies function within the same, very tight social and political frame, and have great respect for dense networks of family and other social ties.

\section{Discussion, generalisations and conclusions}

Semi-structured interviews are a solid methodological tool for getting the correct information about the problems that the agency model causes in the transitional period combined with the process of Europeanisation. We managed to get access to well-informed and honest interviewees. The findings clearly point out that the majority of problems regarding agencies in the three particular SEE countries are related to the systematic legal regulation of agency structure and functioning, and to the introduction of usually employed management tools and steering mechanisms (performance management, reporting). Certain problems have a contextual background, both related to the general administrative system of a particular country (levels of politicisation, professionalism and capacity of the ministries, civil services' particularities) and the society (low trust, economic crisis, democratic control, na- 
ture and density of social networks, societal culture, smallness, scarce human and other sources, etc.).

First, the absence or significant inadequacy of the legal framework for agencies is accentuated by the interviewees as one of the main bases of agency problems in all three countries:

a) Existence of a special law on public agencies. In Croatia and Montenegro, such a special law does not exist, allowing for a great variety in agency structure, uncontrolled proliferation of agencies, and a lack of precise regulation of governance structure, relationships with the line ministry, reporting channels and requirements, performance management and control, relations with users, transparency and other aspects of agency governance. Insufficient regulation leads to unregulated agency governance and accentuates the problems of control. Although the Slovenian Law on Public Agencies is perceived as a good piece of legislation, it has exhibited certain implementation inadequacies, especially with regard to the restricted autonomy and unclear distinction between regulatory and other agencies.

b) Legal status of employees. Employees in various agencies are not treated equally, or their status differs from the status of other state and/or public servants in the respective countries. Such a situation, for example in Croatia, leads to the general perception that agency employees are not public servants, although agency managers do not see this as a problem. In Slovenia, on the other hand, they believe the agency employees should not fall under the public remuneration system, interpreting that as a matter of agency autonomy.

c) Legal regulation of financial autonomy. Financial regulation does not treat agencies properly - in Slovenia and Montenegro their financial autonomy is restricted even to a greater extent than the autonomy of state administration, while in Croatia agencies apply different financial regulations.

d) Weak legal regulation opens space for side politicisation effects. The problem of an inadequate legal framework intensifies both the problems of autonomy and the problems of control, and allows for more discretion on the side of politicians, especially in times of crisis. For example, the current crisis in the circumstances of unclear agency legislation enables the manipulation with the establishment and abolition of agencies, their financing arrangements, appointments of managers and employees, etc. for political purposes.

In sum, the interviewees have accentuated the necessity of creating a legal framework which would clearly differentiate between various types of agencies; regulate the grounds for the establishment and abolition of agencies (including the sunset clauses); establish a mainly professional, technocratic governance structure; and carefully balance their autonomy with regard to management (including personnel and financing) and decision-making (procedure, relations with the 
users), with clearly prescribed control mechanisms (reporting, relations with the ministries, governments and parliaments, performance criteria). The clear legal framework would lower politicisation and enhance the quality of functioning of the agencies, and would help to promote the agencies as a valuable organisational tool. However, the Slovene example shows that the legal framework for agencies that is not carefully designed and adequately assessed and periodically evaluated may accentuate certain problems of the agency model. In its present form, it undermines the agencies' autonomy in the functional, financial and human resources aspect. It is also clear that a different regulatory approach is needed for regulatory agencies, in comparison to other types, despite the fact that several interviewees tend to blur the differences between various kinds of agencies.

Another important legal problem that has been identified in this comparative research relates to the regulation of administrative procedure and administrative justice control that does not fit into the agency model.

a) In all three countries, the laws on general administrative procedure do not contain special provisions adapted to agency proceedings, especially to the proceedings before independent regulatory agencies. Because of that, special procedural regulations have been introduced by sectoral laws, sometimes restricting or opposing general principles of administrative procedure, even the standards established by the European Court of Human Rights.

b) However, even in the cases when special administrative procedural rules are in line with the general administrative procedural legislation, the problem of different arrangements aggravates the problems of legal complexity, legal certainty and the rule of law.

c) The present situation also accentuates the problem of familiarity with the procedural law by the agency employees, which has been particularly underlined by the administrative court judges.

d) What is needed is to find a balance between the necessity for fast and effective decisions in individual cases on the one hand, and sufficient protection of the parties on the other. In this sense, agencies require special treatment in comparison to the central state administration, which would allow only the accommodation of necessary special procedural provisions for particular agencies.

e) In addition, administrative supervision, as reported by the interviewees in Montenegro and Croatia, is inefficient, due to the general legal and structural problems related to administrative supervision in general.

f) Finally, the administrative court control of the agencies' decisions is perceived as being quite good in all three states, although significant improvements should be made regarding the length of court proceedings, and the competence of judges in relation to the highly specialised and complex content of the agency decisions that fall under judicial control. 
Third, the most visible problems related to the effectiveness and the capacity of agencies are not related to the agencies themselves and their staff's expertise, which is generally perceived as high. Rather, they are dependent on the possibility of the labour market to offer specialists in different agency fields, as well as on general ethical standards and the level of professionalism in public administrations, which could be accentuated by the small-state context. However, the most urgent issues of effectiveness are related to the general capacity of political bodies and state administrations to develop sectoral policies, to create better coordination mechanisms between the line ministries and the agencies, as well as between the agencies in the field, and to properly apply the performance management and performance contracts as modern management tools. The insufficient capacity of ministries to recognise and build relations with the agencies and their legalistic approach has been frequently accentuated by the interviewees, both those from the agencies and those from the ministries. An additional issue in Slovenia and Montenegro is the financial management of the agencies, which is restricted by the general framework. It is also a problem in Croatia, where it has been recently restricted due to the crisis. Finally, transparency is related not only to the fatally underdeveloped performance indicators, but also to the fact that the small communities of specialists lead to interconnections between the respective sectors and the agencies and might lead to informal pressures and capture, especially in the context of incomplete legal frameworks. All these circumstances limit the agencies' capacity and effectiveness.

Fourth, a mere regulation of agency structure and functioning is not a sufficient condition for independence and political neutrality, especially if the framework allows for many exceptions, as accentuated in the case of Slovenia. The complete absence of a legal framework for agencies and the different regulation for particular agencies makes this goal even more unattainable, especially in the context of widespread politicisation in administration in general, as in Croatia and Montenegro. Informal autonomy and political independence still depend on the political relations in the system, and the agency landscapes in all three countries show that the autonomy "must be earned by the agencies". Interestingly, the degree of politicisation is clearly visible in administrative disputes related to the appointments of agency managers. Formally defined types of political control, such as annual reporting, are perceived as formalistic and inefficient in fostering effectiveness and good performance. Sometimes, they open additional opportunities to undermine the political independence of the agencies, as in the Montenegrin case. What also contributes to the problem is the fact that the parliaments have a low capacity and are generally not interested in exercising their accountability instruments towards agencies. In general, political-democratic control and the political independence of the agencies are reported to be resulting from the general degree of politicisation within the administrative system, especially in Montenegro, and a low degree of trust, especially in Croatia and Slovenia. In addition, good governance practice, which would replace direct politicisation as a steering mechanism (reporting, per- 
formance management, professional appointments, coordination, transparency), is still in a nascent state in the public administrations of the three countries. The fact that the countries are at different levels of their political and administrative development also reflects on the level of good governance and the rule of law as its integral part, with the Slovenian agency model being the most developed, but still suffering from many inadequacies. This process might be stimulated by more a transparent establishment, structure and functioning of the agencies, thus preventing politicisation and ensuring effectiveness. These goals could be achieved by a clear, adequate and more systematically developed legal framework, which would regulate all relevant aspects of the agency model and ensure their implementation. This would also help to build a positive perception of agencies by the general public and the media, which would also have an opportunity to exercise their democratic control over agencies.

Finally, in the countries with a legalistic tradition in public administration, there is a strong need for precise and appropriate legal instruments to facilitate framing the agency as a relatively new institution and to make it function properly, meaning with sufficient autonomy and the right amount of control. This is a necessary, but, unfortunately, not the only precondition for an institutional stabilisation of the agency and for better management of public affairs. Conversely, politicians feel free to play with the agency as an institution whenever it suits them. Deep politicisation of public administration - agencies included - in this part of Europe seems to continue, undermining the expertise, professionalism and meritocracy at the expense of their citizens, businesses and society in general.

The comparison of the three countries shows that the institutionalisation of the agency model in the context of the changing environment should be underpinned by a strong and clear legal regulation of the structure and functions of agencies, and by an adaptation of other legislative components (personnel, financial, procedural, judicial) to the new institutional form, not vice versa. Although the agencification trajectories are different in the three countries, they actually present what is regularly perceived as being acceptable in public administration. In Slovenia this is a legal framework that allows informally different behaviour; in Croatia this is the absence of a legal framework that would create order and legality; in Montenegro this is a significant politicisation of agencies and other parts of administration within the existing legal framework. The quality of agencies' environment is crucial for their functioning in all three countries - the judiciary, the ministries, the parliaments, the media and the public have significant roles. Greater advancement in democratisation, administrative reform and the quality of the judiciary could add to a better framework and functioning of the agencies.

Smallness of a state can add substantially to the intensity of the agency model's problems and make their resolve harder. Small states can mobilise only a small number of people with real expertise in an agency field. Such experts used to be 
engaged by the regulated and controlled service providers in the respective fields. The tendency to level salaries in the whole public sector, including public agencies of all kinds, which is observable in all three countries especially because of austerity measures, does not motivate rare experts to apply for or to stay in the public service. Even when they are employed by public agencies, they are primarily loyal to their respective expert communities, not to public agencies, sharing information with colleagues employed by companies and other members of respective communities of specialists. Furthermore, the political actors can easily endanger small expert communities. Some members may have political ambitions or may serve, because of interconnections between societal elites, as linking pins to politics. Politics controls all sorts of resources and can easily interrupt expert communities in small countries. That is why some agencies try to please the dominant political actors. However, some well-established agencies with their own revenues, such as telecommunication and similar agencies, can exert strong informal influence on legislation, even on judicial decisions, by buying, shaping and spreading support networks to all relevant societal sectors, which is a much easier endeavour in smaller than in larger countries. These are only some results observed within the research that show the critical importance of the state smallness for the stabilisation of the agency model.

The empirical research based on semi-structured interviews with agency managers, state functionaries and administrative judges in three SEE countries that have not been in the limelight of European administrative science enables us to get closer to the perceptions, standpoints and experience of the main players on the agency court in this particular region. The research asks for continuation in several directions, for example widening the group of countries, clarifying and researching the differences between agencies and traditional public-administrative organisations, conducting more methodologically rigorous and/or quantitative research. This first attempt has given us a solid base for further effort by helping us to develop, at least, a good comprehension frame.

\section{References}

Bohinc, Rado. 2005. Osebe javnega prava: Javni zavodi, javna podjetja, javne agencije, javni skladi. Ljubljana: GV Založba.

Brown, D. R. 2010. "Institutional Development in Small States: Evidence from the Commonwealth Caribbean." Halduskultuur - Administrative Culture 11, $44-65$.

Christensen, Tom and Per Lægreid (eds). 2006. Autonomy and Regulation: Coping with Agencies in the Modern State. Cheltenham, UK and Northampton, MA, USA: Edward Elgar. 
Goetz, Klaus. 2005. "The New Member States and the EU: Responding to Europe." In Simon Bulmer and Christian Lequesne (eds). The Member States of the European Union. Oxford, UK: Oxford University Press, 254-280.

Interviews (January 2012), with managers and board members of the Securities Market Agency (ATVP), The Agency of the Republic of Slovenia for Public Legal Records and Related Services (AJPES), Agency for Public Oversight of Auditing (ANR), Energy Agency (AGEN-RS), Slovenian Research Agency (ARRS), Slovenian Traffic Safety Agency (AVP), Slovenian Book Agency (JAK), Ministry of the economy, Ministry of transport, Ministry of high education, science and technology and Administrative Court in Republic of Slovenia.

Interviews (January 2012) with managers and board members of Croatian Post and Electronic Communication Agency, the Railway Market Regulatory Agency, Croatian Competition Agency, Agency for Science and Higher Education, Croatian Agency for Compulsory Oil Stocks, Croatian Financial Services Supervisory Agency, judges of the Administrative Court of the Republic of Croatia, public officials and highly ranked civil servants in Ministry of labour and the Ministry of Public Administration.

Interviews (January 2012), with managers of the Agency for Electronic Communications and Postal Services, Agency for Medicines and Medical Devices, Tobacco Agency, Environmental Protection Agency, the president, a judge, and a court advisor of the Administrative Court of Montenegro, two assistant ministers (for public administration, Ministry of Internal Affairs; and for internal market and competition, Ministry of Economy).

Koprić, Ivan. 2012. "Managing Public Affairs in South Eastern Europe: Muddled Governance." In Ann Marie Bissessar (ed.). Governance: Is It for Everyone? New York: Nova Publishers (forthcoming).

Koprić, Ivan. 2011a. "Contemporary Croatian Public Administration on the Reform Waves." Yearbook of Croatian Academy of Legal Sciences 2(1), 1-39.

Koprić, Ivan. 2011b. "Administrative Technology and General Administrative Procedure: Challenges and Changes in South-Eastern Europe." Hrvatska i komparativna javna uprava - Croatian and Comparative Public Administration 11(2), 435-454.

Koprić, Ivan, Anamarija Musa and Goranka Lalić Novak. 2012. Europski upravni prostor - European Administrative Space. Zagreb: Institut za javnu upravu.

Kovač, Polonca. 2011. "The Public Administration Reform Agenda in Slovenia: Two Decades of Challenges and Results." Hrvatska i komparativna javna uprava $11(3), 627-650$. 
Kovač, Polonca. 2006. Pravni in sociološki vidiki javnih pooblastil v Sloveniji. Ljubljana: Fakulteta za upravo Univerze v Ljubljani.

Kovač, Polonca and Gregor Virant (eds). 2011. Razvoj slovenske javne uprave 1991-2011. Ljubljana: Uradni list Republike Slovenije.

Lilić, Stevan. 2010. "Pravci unapređenja državne uprave Crne Gore: Ekspertska vizija." In Mijat Šuković (ed.). Crna Gora u XXI stoljeću: U eri kompetitivnosti. Podgorica: Crnogorska akademija znanosti i umjetnosti, 324-345.

Marković, Milan. 2007. Savremena javna uprava. Podgorica: Pravni fakultet, Fakultet političkih nauka.

Musa, Anamarija and Ivan Koprić. 2011. "What Kind of Agencification in Croatia? Trends and Future Directions." Transylvanian Review of Administrative Sciences, Special Issue, November 2011, 50-72.

Olsen, Johan P. 2003. “Towards A European Administrative Space." Journal of European Public Policy 10(4), 506-531.

Parrado, Salvador and Miquel Salvador. 2011. "The Institutionalizing of Meritocracy in Latin American Regulatory Agencies." International Review of Administrative Sciences 77, 687-712.

Pirnat, Rajko. (ed.). 2004. Komentar zakonov s področja uprave. Ljubljana: Inštitut za javno upravo pri Pravni fakulteti.

Pirnat, Rajko. 2000. "Nekatera vprašanja postopkov neodvisnih upravnih agencij." Podjetje in delo (6/7), 1393-1402.

Polidano, Charles. 1999. "The Bureaucrat Who Fell Under a Bus: Ministerial Responsibility, Executive Agencies and The Derek Lewis Affair in Britain." Governance: An International Journal of Policy and Administration 12(2), 201-229.

Pollitt, Christopher. 2004. "Clarifying Convergence: Striking Similarities and Durable Differences in Public Management Reform." Public Management Review 4(1), 471-472.

Pollitt, Christopher and C. Talbot (eds). 2004. Unbundled Government: A Critical Analysis of the Global Trend to Agencies, Quangos and Contractualization. London and New York: Routledge.

Randma-Liiv, Tiina. 2002. "Small States and Bureaucracy: Challenges for Public Administration." TRAMES 6(4), 374-389.

Sarapuu, Külli. 2010. "Comparative Analysis of State Administrations: The Size of State as an Independent Variable." Halduskultuur - Administrative Culture 11(1), 30-43. 
Schimmelfennig, Frank and Ulrich Sedelmeier (eds). 2005. The Europeanization of Central and Eastern Europe. Ithaca, London: Cornell University Press.

Šević, Željko. 2001. "Politico-Administrative Relationship in Small States." Bank of Valetta Review 23, 63-76.

Van Thiel, Sandra. 2012. "Comparing Agencies across Countries." In K. Verhoest, S. van Thiel, G. Bouckaert and P. Lægreid (eds). Government Agencies: Practices and Lessons from 30 Countries. Basingstoke: Palgrave Macmillan, 18-26.

Verhoest, Koen, Sandra van Thiel, Geert Bouckaert and Per Lægreid. 2012. Government Agencies: Practices and Lessons from 30 Countries. Basingstoke and New York: Palgrave Macmillan.

Verhoest, Koen, Sandra van Thiel, Geert Bouckaert and Per Lægreid. 2011. Governing Public Agencies in the $21^{\text {st }}$ Century, COST Policy Brief. Leuven: K. U. Leuven, Public Management Institute.

Virant, Grega. 2004. "Prenos nalog javne uprave na nedržavne organizacije: Primerjalni in teoretični okviri." Podjetje in delo (6-7), 1411-1418.

Vlada RS/Government of the Republic of Slovenia. 2011. Izhodišča za nadaljnji razvoj in organizacijsko ter normativno urejanje javnega sektorja [The Origins of further development and organisational and normative regulation of the public sector], internal unpublished materials. 


\section{Appendix:}

\section{Overview of the Main Characteristics of the Countries}

\begin{tabular}{|c|c|c|c|}
\hline & Slovenia & Croatia & Montenegro \\
\hline Population* & $2,049,261$ & $4,290,612$ & 625,266 \\
\hline Size $\left(\mathrm{km}^{2}\right)^{*}$ & 20,273 & 56,542 & 13,812 \\
\hline $\begin{array}{l}\text { Capital (population } \\
\text { in } 1,000)^{*}\end{array}$ & Ljubljana (253) & Zagreb (793) & Podgorica (187) \\
\hline $\begin{array}{l}\text { GDP per capita } \\
2010^{*}(€)\end{array}$ & 15,300 & 8,500 & $4,720(2009)$ \\
\hline $\begin{array}{l}\text { GDP as percentage } \\
\text { of EU } 27 \text { average, in } \\
2010\end{array}$ & 85 & 61 & 41 \\
\hline Independence & 1991 & 1991 & 2006 \\
\hline Type & $\begin{array}{l}\text { parliamentary } \\
\text { democracy }\end{array}$ & parliamentary democracy & $\begin{array}{l}\text { parliamentary } \\
\text { democracy }\end{array}$ \\
\hline $\begin{array}{l}\text { Territorial } \\
\text { governance }\end{array}$ & 212 local units & $\begin{array}{l}556 \text { local units } \\
20 \text { counties }\end{array}$ & 21 local units \\
\hline EU relations & $\begin{array}{c}\text { AA } 1996 \\
1997 \text { candidate } \\
\text { status } \\
1998-2002 \\
\text { negotiations } \\
2003 \text { accession } \\
\text { treaty signed } \\
2004 \text { membership }\end{array}$ & $\begin{array}{c}2001 \text { SAA } \\
2005 \text { candidate status } \\
2005-2011 \text { negotiations } \\
2012 \text { accession treaty } \\
\text { signed } \\
\text { (membership expected } 1 \\
\text { July 2013) }\end{array}$ & $\begin{array}{c}2007 \text { SAA } \\
2010 \text { candidate } \\
\text { status } \\
\text { (negotiations in } \\
2012 \text { ) }\end{array}$ \\
\hline $\begin{array}{l}\text { GDP annual growth } \\
2009 \text { and }(2010)^{* *}\end{array}$ & $-8.0(1.4)$ & $-6.0(-1.2)$ & $-5.7(2.5)$ \\
\hline $\begin{array}{l}\text { Unemployment rate } \\
2009^{* *}\end{array}$ & 5.9 & 9.1 & N/A \\
\hline $\begin{array}{l}\text { Corruption } \\
\text { perception index } \\
2011 \text { (rank)*** } \\
\end{array}$ & $5.9(35)$ & $4.0(66)$ & $4.0(66)$ \\
\hline $\begin{array}{l}\text { Doing business } \\
2011 \text { rank/183 } \\
\text { countries**** }\end{array}$ & 42 & 84 & 66 \\
\hline The rule of law***** & 82.5 & 60.7 & 55.0 \\
\hline $\begin{array}{l}\text { Government } \\
\text { effectiveness } * * * * *\end{array}$ & 81.3 & 70.3 & 57.9 \\
\hline $\begin{array}{l}\text { Regulatory } \\
\text { quality*****}\end{array}$ & 74.6 & 70.3 & 51.7 \\
\hline $\begin{array}{l}\text { UN e-government } \\
\text { ranking****** }\end{array}$ & 29 & 35 & 60 \\
\hline
\end{tabular}

${ }^{\star}$ Data retrieved from the national statistical offices and the Eurostat

** The World Bank, http://data.worldbank.org/

${ }^{* * *}$ www.transparency.org

$* * * *$ www.doingbusiness.org

${ }_{* * * * *}$ The World Bank Governance Indicators, http://info.worldbank.org/governance/wgi/index.asp

$* * * * * *$ UN DPADM E-government:

http://www.unpan.org/DPADM/EGovernment/UNEGovernmentSurveys/tabid/600/language/ en-US/Default.aspx 